\title{
PENGEMBANGAN BUKU SAKU SEBAGAI MEDIA PROMOSI KESEHATAN TENTANG CACINGAN YANG DITULARKAN MELALUI TANAH PADA SISWA KELAS IV SDN O1 KROMENGAN KABUPATEN MALANG
}

\author{
Andi Ahmad, Sapto Adi, Rara Warih Gayatri \\ Fakultas Ilmu Keolahragaan Universitas Negeri Malang \\ E-mail: andiahmadd@gmail.com
}

\begin{abstract}
The prevalence of soil transmitted helminth at SDN 01 Kromengan reached $48 \%$ and higher when it's compared to other schools in Malang Regency. Soil transmitted helminth prevalence of fourth grade students reached $61.25 \%$ and became the highest of the other classes. According to Andini (2015), it is advisable to provide a posters as a health promotion media. Since it only has a little material coverage and can't be taken anywhere, while the facilities and infrastructure is not sufficient for other media then it is necessary to develop the appropriate media that is a pocket book. The development model used is a procedural model with adopted steps according to Sugiyono (2016). The analysis technique used is quantitative analysis technique that is descriptive analysis and qualitative analysis technique. The result of this research and development is a pocket book titled "Aku Anak Sehat Bebas Cacingan". It contains the definition of helminthiasis, soil transmitted helminth, the kinds, the dangers, the trans-mission mode, the prevention and the treatment of it. Assessment by material expert and media expert shows the percentage of $75 \%-100 \%$ and categorized as feasible and highly feasible on every aspect of their assessment. The first and second trial step result shows the precentage are above $90 \%$ then categorized as highly feasible. The final product result of the "Aku Anak Sehat Bebas Cacingan" pocket book is still unclear how much impact on the increase of students knowledge, therefore it is necessary to do further research related to it.
\end{abstract}

Keywords: pocket book, health promotion media, helminthiasis, soil.

\begin{abstract}
Abstrak: Prevalensi cacingan yang ditularkan melalui tanah di SDN 01 Kromengan mencapai $48 \%$ dan lebih tinggi dibandingkan dengan sekolah lain di Kabupaten Malang. Prevalensi pada kelas IV mencapai $61,25 \%$ dan menjadi yang tertinggi dari kelas lainnya. Menurut Andini (2015), disarankan memberikan media promosi kesehatan berupa poster. Karena poster hanya memiliki cakupan materi sedikit dan tidak dapat untuk dibawa kemana-mana, sedangkan sarana dan prasarana belum memadai untuk media lain maka perlu dikembangkan media lain yaitu buku saku. Model pengembangan yang digunakan adalah model prosedural dengan mengacu langkah-langkah pengembangan menurut Sugiyono (2016). Teknik analisis data yang digunakan adalah teknik analisis kuantitatif yaitu analisis deskriptif dan teknik analisis kualitatif. Hasil dari penelitian dan pengembangan ini adalah sebuah buku saku dengan judul “Aku Anak Sehat Bebas cacingan”. Buku saku ini berisi materi tentang pengertian cacingan, cacingan yang ditularkan melalui tanah, macamnya, bahayanya, penularannya, pencegahan dan pengobatannya. Penilaian yang dilakukan oleh ahli materi dan ahli media menunjukkan angka 75\%-100\% yang dikategorikan layak dan sangat layak pada setiap aspek penilaiannya. Berdasarkan hasil uji coba 1 dan 2 presentase yang dihasilkan di atas angka 90\% sehingga tergolong sangat layak. Hasil produk akhir buku saku "Aku Anak Sehat Bebas Cacingan" masih belum diketahui berapa besar pengaruhnya terhadap peningkatan pengetahuan siswa, maka perlu penelitian lanjutan terkait hal tersebut.
\end{abstract}

Kata Kunci: buku saku, media promosi kesehatan, cacingan, tanah. 
Cacingan adalah salah satu bagian dari masalah kesehatan masyarakat dan termasuk penyakit berbasis lingkungan dengan media penularan melalui tanah sehingga disebut dengan Soil Transmited Helminth (STH) (Martila, 2015). Sofiana (2011) menjelaskan bahwa infeksi cacingan ini dapat berpengaruh pada pertumbuhan dan perkembangan anak. Infeksi penyakit pada anak juga dapat mengakibatkan prestasi akademik menurun karena berhubungan dengan penurunan jumlah kehadiran siswa di kelas (Moonie, 2008).

Berdasarkan penelitian oleh Andini (2015), pemeriksaan cacing pada kuku sejumlah 48 siswa kelas I-VI di SDN 01 Kromengan Kabupaten Malang dihasilkan data prevalensi cacingan yang ditularkan melalui tanah mencapai angka $48 \%$. Angka tersebut tergolong dalam kategori sedang dan prevalensi tertinggi salah satunya ada pada siswa kelas III sebesar $61,25 \%$ (pada tahun 2017 sudah naik ke kelas IV).

Prevalensi cacingan ysng ditularksn melalui tanah di SDN 01 Kromengan ini termasuk lebih tinggi jika dibandingkan dengan prevalensi pada siswa SDN 01 Ngajum Kabupaten Malang yaitu dari 40 siswa yang diperiksa hanya ada $25 \%$ yang positif terinfeksi cacingan yang ditularkan melalui tanah (Tristyanto dan Faisal, 2011). Data cacingan yang diperoleh pada penelitian lain oleh Faisal (2013) di SDI 03 Salafiah Singosari Kabupaten Malang juga tidaklah lebih tinggi yaitu hanya $23 \%$ dari 30 siswa.

Berdasarkan observasi peneliti dan menurut Andini (2015), penularan cacingan di SDN 01 Kromengan ini dipengaruhi rendahnya kebersihan diri dan lingkungan, meliputi kebiasaan mencuci tangan, kebiasaan membeli jajanan di sekolah yang dijajakan tanpa penutup sehingga terkontaminasi cacing, dan 4 dari 18 siswa pada kelas IV juga sering melepaskan sepatu mereka di sekolah. Kebiasaan pada masyarakat yang masih menggunakan sungai untuk sarana MCK (Mandi Cuci Kakus) dan juga kebiasaan BAB (Buang Air Besar) di area kebun juga mejadi penyebab infeksi cacingan yang ditularkan melalui tanah. Kurangnya kebersihan diri dan lingkungan di SDN 01 Kromengan ini disebabkan oleh rendahnya pengetahuan yang dimiliki oleh siswa (Andini, 2015). Masalah tersebut menjadikan siswa sekolah dasar menjadi bagian masyarakat yang rentan terhadap penularan penyakit termasuk cacingan yang ditularkan melalui tanah (Astuty, 2009).

Berdasarkan penelitian oleh Andini (2015), diberikan saran untuk memberikan media promosi kesehatan berupa poster pada siswa. Akan tetapi poster memiliki kekurangan yaitu tidak mampu digunakan untuk menyampaikan pesan dalam jumlah yang banyak dan ketika dipasang pada tempat tertentu seperti tembok sekolah poster rentan terhadap cuaca (Okdila, 2013). Kondisi keterbatasan sarana dan pra-sarana yang ada di SDN 01 Kromengan juga menjadi kendala tersendiri untuk dikembangkan media lain berupa audio maupun berupa audio visual karena pada media jenis ini membutuhkan dukungan peralatan yang lain yang belum dimiliki. Maka dari itu media yang dapat dikembangkan adalah dalam bentuk media visual saja.

Menurut Adisendjaja dan Romlah (dalam Ami, 2012), mengemukakan bahwa jenis media visual yang sering digunakan siswa di sekolah adalah buku pelajaran, akan tetapi karena uraian pada bacaan relatif panjang dan juga ukuran yang besar membuat minat baca siswa menurun. Alternatif media lain adalah buku saku karena memiliki uraian yang tidak terlalu panjang disertai gambar dan warna yang menarik (Wardhani dalam Ami, 2012). Buku saku ini juga dapat membuat proses belajar menjadi lebih efisien dalam waktu dan tenaga, karena dicetak dalam ukuran kecil sehingga mudah dibawa dan dapat dimanfaatkan kapanpun dan dimanapun.

Menurut hasil wawancara peneliti dengan pembina UKS, buku saku ini dapat menjadi media promosi kesehatan pertama di SDN 01 Kromengan karena belum pernah ada sebelumnya. Selain itu pengembangan buku saku merupakan langkah pertama dalam upaya pencegah- 
an penularan cacingan melalui tanah di SDN 01 Kromengan.

Berdasarkan paparan latar belakang tersebut peneliti melakukan penelitian dan pengembangan sebuah buku saku yang digunakan sebagai media promosi kesehatan dengan materi cacingan yang ditularkan melalui tanah pada sasaran siswa kelas IV di SDN 01 Kromengan Kabupaten Malang.

Penelitian dan pengembangan ini bertujuan untuk menghasilkan sebuah media promosi kesehatan berupa buku saku tentang cacingan yang ditularkan melalui tanah bagi siswa kelas IV SDN 01 Kromengan Kabupaten Malang Jawa Timur.

Promosi kesehatan sendiri merupakan pembaruan dari penggunaan kata pendidikan kesehatan yang mana kedua istilah ini dapat disamakan karena tetap mengedepankan visi dan misi utama dari pendidikan kesehatan yaitu masyarakat dapat berperilaku hidup sehat, dalam arti masyarakat tahu, mau dan mampu untuk memelihara dan meningkatkan kesehatan mereka secara pribadi (Notoatmodjo, 2011).

Pelaksanaan kegiatan promosi kesehatan memerlukan bantuan dari media promosi kesehatan. Media promosi kesehatan adalah sarana yang digunakan untuk menyampaikan suatu pesan dalam meningkatkan pengetahuan pada sasaran sehingga pada akhirnya dapat merubah perilakunya kearah lebih sehat (Supiyati dan Eny, 2011). Jenis media promosi kesehatan yang digunakan harus dipilih dengan mpertimbangkan access, cost, technology, interactivity, organization dan novelty (Kholid, 2015).

Buku saku adalah buku kecil yang memiliki jumlah halaman yang tidak lebih dari 30 halaman bolak balik yang berisikan tulisan disertai gambar serta berukuran kecil dan tipis sehingga dapat dimasukkan kedalam saku baju (BPTP Jambi, 2016). Menurut Sulistyani, dkk. (2013), untuk menghasilkan buku saku yang baik harus memperhatikan beberapa hal, yaitu:

a. Penggunaan istilah dan simbol harus b. Materi ditulis secara singkat dan jelas

c. Tulisan dalam isi buku saku disusun dengan baik sehingga dapat dengan mudah dipahami

d. Desain dan warna dibuat menarik.

e. Jumlah halaman juga harus genap untuk menghindari adanya halaman kosong.

Materi cacingan dalam sebuah buku saku juga harus disajikan dalam bentuk gambar dan bahasa yang sesederhana mungkin sehingga dapat dengan mudah dipahami sasaran (Novita dan Yunetra, 2011). Selain kemudahan dipahami, materi dalam sebuah buku saku harus dibuat dengan tetap mempertimbangkan segi kebermanfaatan dari sebuah media promosi kesehatan tersebut yaitu untuk memudahkan sasaran mengingat pesan yang disampaikan, sehingga materi yang disajikan harusnya dibuat untuk mudah diingat oleh sasaran yang membacanya (Hikmawati, 2011).

Siswa usia kelas IV sekolah dasar termasuk dalam kategori kelas tinggi bersama-sama dengan kelas $\mathrm{V}$ dan VI (Rahayu, 2015). Usia rata-rata Siswa kelas IV adalah 10 tahun dan memiliki kemampuan untuk memahami kalimat yang rumit dalam bacaan sudah lebih baik jika dibandingkan dengan kelas sebelumnya (1, 2, 3) (Sitepu, 2015). Menurut Sandjaja (2001), pada usia kurang lebih 10 tahun anak lebih menyukai buku dengan perbandingan komposisi tulisan lebih banyak daripada gambar dan menyukai bacaan yang lebih realistik. Menurut Sitepu (2015), untuk anak kelas IV sekolah dasar dapat diberikan buku dengan perbandingan antara teks dan gambar yaitu 70\%:30\%. Anak usia kelas IV sekolah dasar dalam perkembangan kognitif termasuk dalam tahap operasional konkret yaitu tahap dimana kemampuan belajar konsep lebih meningkat termasuk juga kemampuan dalam ingatan dan berpikir secara logis (Soetciningsih dan Ranuh, 2013).

World Health Organizatio (WHO) mengemukakan bahwa cacingan yang ditularkan melalui tanah yaitu kelompok cacing yang pematangan larvanya untuk menjadi infektif terjadi di dalam tanah 
(Natadisastra, 2009). Adapun jenis cacingan yang ditularkan melalui tanah adalah Ascaris lumbricoides atau cacing gelang, Trichuris trichiura atau cacing cambuk serta Ancylostoma duodenale atau jenis cacing tambang (Centers for Desease Control and Prevention, 2013).

Bahaya ditimbulkan akibat infeksi cacingan yang ditularkan melalui tanah salah satunya penurunan status gizi pada penderitanya, pada anak-anak juga dapat menyebabkan adanya komplikasi berat yaitu obstruksi usus, diare berdarah dan kekurangan darah atau anemia (WHO, 2006, Tjay dan Rahardja, 2010). Selain itu jenis cacing tambang dapat menyebabkan timbul adanya ruam yang menonjol pada kulit dan juga kesulitan bernafas pada penderita cacingan jenis ini (Widodo, 2013).

Penularan cacingan melalui tanah jenis cacing gelang dan cacing cambuk dapat ditularkan melalui perpindahan telur cacing dari kotoran ke mulut yang disebabkan kurangnya kebersihan dan perilaku buang air besar di sembarang tempat (Werner, dkk., 2010). Selain itu pada cacingan jenis ini juga dapat ditularkan melalui makanan dan air yang telah terinfeksi dan kemudian masuk ke tubuh (Tjay dan Rahardja, 2007). Untuk cacing tambang selain masuk me-lalui mulut juga dapat ditularkan melalui masuknya larva menembus kulit kaki yang menimbulkan suatu reaksi di area sekitarnya (Tjay dan Rahardja, 2007 dan Pribadi, 2011).

Muslim (2009) mengemukakan bahwa upaya pencegahan cacingan yang ditularkan melalui tanah secara umum dapat dilakukan dengan pengobatan baik secara individu maupun secara massal, menghindari kontak langsung dengan debu, menghindari kebiasaan buang air besar di sembarang tempat dan memakai alas kaki ketika beraktivitas. Sedangkan berdasarkan Kementerian Kesehatan RI (2012), upaya dalam mengendalikan dan mencegah terjadinya cacingan yaitu: a. Upaya Promotif

Upaya promotif pengendalian dan pencegahan cacingan dapat dilakukan penyuluhan kepada anak sekolah dasar melalui program oleh Usaha Kesehatan Sekolah (UKS). Upaya promotif juga dapat dilakukan dengan memanfaatkan fungsi media promosi kesehatan yang ada di Puskesmas atau Posyandu. b.

Preventif

Upaya preventif yang dapat dilakukan untuk mencegah penyakit cacingan adalah melalui kegiatan pengendalian faktor resiko yang meliputi kebersihan lingkungan dan kebersihan perorangan melalui penerapan perilaku hidup bersih dan sehat (PHBS).

c. Pengobatan

Menurut Pribadi (2011), ketika terkena cacingan harus segera pergi ke pelayanan kesehatan yaitu Puskesmas ataupun dokter, kemudian minum obat sesuai dengan petunjuk dari dokter dan mencuci pakaian, sprei ataupun mainan untuk memusnahkan sisa telur cacing. Pengobatan infeksi cacingan juga dapat dilakukan dengan cara meminum obat cacingan yang dapat dibeli secara bebas di warung atau apotek yaitu obat jenis Pirantel pamoat (Suwandi dkk., 2002).

\section{METODE}

Model yang digunakan dalam penelitian dan pengembangan ini adalah model prosedural. Model prosedural ini dilaksanakan menggunakan pendekatan deskriptif dengan memaparkan alur atau langkah-langkah yang harus dilakukan dalam menghasilkan produk (Setyosari, 2012).

Penelitian dan pengembangan ini menggunakan prosedur $R \& D$ menurut Sugiyono (2016) dengan urutannya yang telah disederhanakan oleh peneliti berikut ini: 1) identifikasi masalah, 2) mengumpulkan informasi, 3) membuat desain produk awal, 4) validasi oleh ahli (media dan materi) dan revisi, 5) uji coba produk tahap 1 dan revisi, 6) uji coba produk tahap 2 dan produk akhir.

Subjek uji coba dalam penelitian dan pengembangan ini adalah 6 siswa pada uji coba tahap 1 dan 18 siswa pada uji coba tahap 2. Pada uji coba tahap 1 siswa dipilih secara acak. Penentuan jumlah didasarkan pada jumlah subjek uji coba menurut Setyosari (2012) yaitu 
6-8 orang pada kelompok kecil (uji coba tahap 1) dan 15-30 subjek atau seluruh siswa di kelas (a whole class of learners) pada kelompok besar (uji coba tahap 2).

Jenis data yang dihasilkan pada penelitian dan pengembangan ini adalah data kualitatif dan data kuantitatif yang diperoleh melalui proses validasi oleh ahli dan uji coba siswa. Instrumen yang digunakan adalah angket untuk penilaian dengan skala 1-4 mulai dari tidak baik, kurang baik, baik dan sangat baik. Data kualitatif adalah data berupa saran yang dituliskan oleh ahli (media dan materi) dan siswa, sedangkan data kuantitatif adalah data hasil penilaian pada setiap indikator dalam angket validasi yang disisi oleh ahli dan siswa.

Data kualitatif ini dianalisis dengan menyimpulkannya kemudian digunakan secara langsung sebagai dasar perbaikan buku saku. Sedangkan data kuantitatif yang berupa nilai dianalisis berdasarkan persentase dengan mengacu pada acuan intrepretasi menurut Suharsimi Arikunto (dalam Saidah, 2015) berikut:

$100 \%$

Tabel 1 Penilaian Kelayakan

\begin{tabular}{ccc}
\hline $\begin{array}{c}\text { Persentase } \\
\text { Penilaian }\end{array}$ & Interpretasi & Keterangan \\
\hline $76 \%-100 \%$ & Sangat layak & Sangat Baik digunakan \\
\hline $51 \%-75 \%$ & Layak & Baik digunakan dengan revisi kecil \\
\hline $26 \%-50 \%$ & Kurang Layak & Boleh digunakan dengan revisi besar \\
\hline $0 \%-25 \%$ & Tidak Layak & Tidak boleh digunakan \\
\hline
\end{tabular}

\section{Sumber: Suharsimi Arikunto (dalam Saidah, 2015)}

\section{HASIL}

\section{Hasil Analisis Kebutuhan}

Tahap awal yang dilakukan adalah analisis kebutuhan spesifikasi buku saku yang diinginkan siswa. Hasil analisis kebutuhan tersebut menghasilkan data berdasarkan pilihan spesifikasi dengan jumlah pemilih terbanyak yaitu:

a. Ukuran buku saku $8 \times 11 \mathrm{~cm}$

b. Judul buku saku "Aku Anak Sehat, Bebas Cacingan"

c. Warna dasar

d. Jenis gambar adalah asli dan kartun

e. Bentuk hiasan bebas f. Gambar ada pada setiap halaman

g. Kata ilmiah perlu dicantumkan

h. Jenis huruf Jokerman (judul buku saku) dan Comic Sans Ms (isi buku saku)

i. Materi tambahan yang dipilih tentang enanganan/pengobatan cacingan yg ditularkan melalui tanah.

\section{Hasil Validasi Ahli Materi}

Produk awal berdasarkan hasil pada analisis kebutuhan selanjutnya dinilai oleh satu ahli materi tentang cacingan, dengan hasil penilaian sebagai berikut:

Tabel 2 Penilaian Ahli Materi

\begin{tabular}{lcl}
\multicolumn{1}{c}{ Aspek } & Persentase & Keterangan \\
\hline Cakupan materi & $100 \%$ & Sangat layak \\
\hline Akurasi materi & $83 \%$ & Sangat layak \\
\hline Aspek Komunikatif & $75 \%$ & Layak \\
\hline Kemutakhiran sumber rujukan & $100 \%$ & Sangat layak \\
\hline Teknik penyajian & $100 \%$ & Sangat layak \\
\hline Pendukung penyajian materi & $88 \%$ & Sangat layak \\
\hline
\end{tabular}


Ahli materi juga memberikan saran perbaikan pada buku saku, yaitu untuk menambahkan sitasi atau referensi pada gambar, menambahkan daftar pustaka, merubah gambar yang memperlihatkan wajah menjadi gambar karikatur atau kartun, mengubah kalimat menjadi lebih efektif, mengubah pesan atau himbauan menjadi lebih mengajak (persuasif), me- nambahkan sumber rujukan jurnal dan memperbaiki gambar ilustrasi menjadi lebih menarik (eye catching).

\section{Hasil Validasi Ahli Media}

Desain produk awal buku saku juga dinilai oleh satu ahli media dengan hasil sebagai berikut:

Tabel 3 Penilaian Ahli Media

\begin{tabular}{lcl}
\hline \multicolumn{1}{c}{ Aspek } & Persentase & Keterangan \\
\hline Ukuran buku saku & $88 \%$ & Sangat layak \\
\hline Desain sampul buku saku & $96 \%$ & Sangat layak \\
\hline Desain isi buku saku & $95 \%$ & Sangat layak \\
\hline
\end{tabular}

Ahli media juga memberikan saran untuk perbaikan desain pada buku saku yaitu menambahkan halaman yang berisi tentang daftar riwayat hidup peneliti, daftar pustaka dan dapat ditambahkan form identitas bagi pemilik buku saku, menambahkan nama penulis di sampul, dengan ukuran font 11 dan pada sampul bagian belakang ditambahkan ringkasan pesan tentang cara mencegah cacingan dengan gambar yang disesuaikan dengan konteks. Saran ahli yang terakhir adalah mengubah latar belakang (background) yang harus disesuaikan dengan gambar utama yang ditampilkan dan mengganti gambar orang asing menjadi gambar orang Indonesia.

\section{Hasil Uji Coba Tahap 1}

Hasil buku saku yang telah direvisi berdasarkan saran dari ahli media dan ahli materi selanjutnya diuji cobakan pada 6 siswa (kelompok kecil) dengan hasil sebagai berikut:

Tabel 4 Hasil Uji Coba Tahap 1

\begin{tabular}{lcl}
\multicolumn{1}{c}{ Aspek } & Persentase & Keterangan \\
\hline Ukuran buku saku & $92 \%$ & Sangat layak \\
\hline Desain buku saku & $97 \%$ & Sangat layak \\
\hline Materi buku saku & $98 \%$ & Sangat layak \\
\hline
\end{tabular}

Pada uji coba tahap 1 siswa memberikan saran perbaikan buku saku yaitu untuk mengganti gambar ilustrasi pada halaman 6 yang menjelaskan tentang gambar anak dengan perut membuncit yang hanya mengenakan celana dengan gambar yang mengenakan baju.

\section{Hasil Uji Coba Tahap 2}

Uji coba tahap 1 ini menghasilkan media berupa buku saku yang telah dilakukan perbaikan berdasarkan saran dari siswa yang selanjutnya diuji cobakan pada 18 siswa (kelompok besar), dengan hasil sebagai berikut:

Tabel 5 Hasil Uji Coba Tahap 2

\begin{tabular}{lcl}
\multicolumn{1}{c}{ Aspek } & Persentase & Keterangan \\
\hline Ukuran buku saku & $95 \%$ & Sangat layak \\
\hline Desain buku saku & $97 \%$ & Sangat layak \\
\hline Materi buku saku & $98 \%$ & Sangat layak \\
\hline
\end{tabular}


Pada uji coba tahap 2 siswa tidak memberikan saran perbaikan untuk buku saku. Berdasarkan data tersebut peneliti menyimpulkan bahwa buku saku yang dinilai siswa pada uji coba tahap 2 ini merupakan produk akhir dari penelitian dan pengembangan buku saku tentang cacingan yang ditularkan melalui tanah.

\section{PEMBAHASAN}

Produk akhir Buku Saku tentang cacingan yang ditularkan melalui tanah dengan judul "Aku Anak Sehat Bebas Cacingan" ini telah dihasilkan melalui prosedur pengembangan yang melalui beberapa proses. Proses tersebut dimulai dari tahap analisis kebutuhan hingga memperoleh hasil produk akhir buku saku yang siap digunakan. Buku saku ini sangat sesuai dengan kondisi sasaran karena disusun berdasarkan kebutuhan spesifikasi yang diinginkan baik dari segi desain grafis maupun materi yang disampaikan. Menurut Widodo (dalam Suiraoka, 2012), karena pembuatan buku saku didasarkan pada kebutuhan sasaran maka dapat dikatakan bahwa pengembangan ini tidak didasarkan atas kesenangan pribadi peneliti.

Kholid (2015) menyatakan bahwa suatu media promosi kesehatan yang baik harus dapat memenuhi kriteria Access, Cost, Technology, Interactivity, Organization dan Novelty. Buku saku "Aku Anak Sehat Bebas Cacingan" ini sangat tepat untuk digunakan sebagai media promosi kesehatan pada sasaran karena kesediaan sarana dan prasarana yang mendukung untuk penggunaan media lain belum cukup tersedia di SDN 01 Kromengan. Berdasarkan hal tersebut maka buku saku termasuk media yang mudah untuk diakses siswa karena tidak perlu membutuhkan alat-alat tertentu untuk penggunaannya (Access).

Pertimbangan berikutnya adalah dari segi biaya (cost) yang dikeluarkan untuk pembuatan buku saku. Buku saku disediakan dalam bentuk cetak, sehingga memerlukan biaya pencetakan. Biaya yang dikeluarkan untuk mencetak satu buku saku tergolong tidak terlalu mahal. Semakin banyak jumlah buku saku yang dicetak maka biaya yang dikeluarkan untuk mencetak setiap buku (unit cost) semakin lebih kecil (Kholid, 2015). Hal tersebut dirasakan juga oleh peneliti, yang mana biaya yang dikeluarkan saat mencetak 20 buku saku pada uji coba kelompok besar (tahap 2) adalah $\mathrm{Rp}$ 124.000 (unit cost, $124.000 / 20=6.200$ ) sedangkan untuk mencetak 6 buku saku dalam uji coba kelompok kecil (tahap 1) di tempat percetakan yang sama adalah Rp 43.500 (unit cost, 43.500/6 = 7.250). Biaya yang dikeluarkan untuk mencetak buku saku ini seharusnya tidak akan menjadi masalah ketika melihat manfaat dan kelebihan yang didapatkan, seperti dapat disebarluaskan pada sasaran yang luas, dapat bertahan lama karena tidak mudah rusak dan dengan ukuran kecil yang dapat dibawa kemana-mana (Sari, dkk., 2010).

Aspek berikutnya yang menjadi kriteria sebagai media yang baik adalah technology. Penggunaan buku saku dari segi teknologi tidak menyulitkan, tidak membutuhkan listrik dan alat lain seperti bantuan sound system ataupun sebuah layar monitor sehingga sesuai dengan keadaan fasilitas pendukung yang ada di SDN 01 Kromengan (Supiyati dan Eny, 2012). Berdasarkan uraian tersebut maka dapat disimpulkan bahwa dari segi teknologi buku saku "Aku Anak Sehat Bebas Cacingan" ini sudah terpenuhi.

Buku saku "Aku Anak Sehat Bebas Cacingan" disusun pula dengan mempertimbangkan dari aspek interaktifitas (interactivity). Penambahan gambar, pemilihan warna dan kalimat-kalimat yang seolah-olah mampu mengajak pembaca berbicara membuat buku saku menjadi menarik untuk dibaca. Adanya gambar pada buku saku membuat buku saku menjadi media penyampian pesan yang sesuai untuk anak sekolah dasar (Husna dan Reliani, 2016). Menurut Nurani dan Nugrahardi (2014), penambahan gambar yang memunculkan interaksi antara buku dan pembaca akan membuat anak lebih senang untuk belajar. Warna dasar hijau, merah muda terang (hot pink), kuning-jingga (yellow orange) dan biru yang ada pada buku saku ini juga 
memliki makna tersendiri terhadap pembaca.

Warna hijau () memiliki makna relaksasi, adanya warna hijau membuat siswa tidak merasakan lelah dikarenakan sifat relaksasi yang diberikan (Sulianta, 2015). Warna merah muda terang ( memiliki sebuah makna kesehatan dan kebugaran sehingga sesuai materi yang disajikan yaitu tentang kesehatan dan diharapkan mampu memotivasi para siswa untuk menjaga kesehatannya (Sanyoto,

2010). Warna kuning-jingga ( $\| \square$ ) memiliki makna ceria, cerah, hangat dan berani, diharapkan warna tersebut dapat membawa siswa kedalam suasana yang ceria ketika sedang membaca dan membuat mereka berani untuk mewujudkan semangat dari "Aku Anak Sehat Bebas Cacingan" (Sulianta, 2015). Warna biru ( I) memiliki makna tenang, bebas serta mendalam yang diharapkan dengan warna biru para siswa dapat fokus dalam mempelajari materi karena sifat tenang yang dimiliki oleh warna biru (Sanyoto, 2010). Berdasarkan hasil kegiatan uji coba baik uji coba 1 maupun uji coba 2, menurut siswa gambar dan warna yang ada pada buku saku juga sangat menarik dan berdasarkan kategori tabel penilaian kelayakan hasil tersebut termasuk dalam kategori sangat layak.

Buku saku "Aku Anak Sehat Bebas Cacingan" ini memenuhi syarat media yang baik lainnya yaitu Organization. Sekolah bersedia memberikan dukungan dalam proses pengembangan buku saku tentang cacingan yang ditularkan melalui tanah ini di SDN 01 Kromengan karena belum tersedia media serupa di sekolah. Terkait dengan pemanfaatannya dari pembina Usaha Kesehatan Sekolah (UKS) menerima dengan baik produk buku saku tersebut sebagai bagian dari kelengkapan dari UKS. Selain diberikan kepada siswa buku saku ini juga dapat membantu dalam pelaksanaan salah satu program Trias UKS yaitu pendidikan kesehatan (Budiono dan Muji, 2014). Dengan adanya sebuah media buku saku keterbatasan dalam kegiatan pendidikan kesehatan ini dapat diantisipasi dengan pendidikan melalui media promosi ke- sehataan, sehingga satu tujuan dari UKS untu meningkatkan kemampuan hidup sehat dan dalam meningkatkan derajat kesehatan peserta didik dapat tercapai (Nurjannah, 2012).

Aspek terakhir yang harus dipenuhi adalah aspek novelty, yaitu keterbaruan. Buku saku ini memang merupakan salah satu jenis sumber belajar konvensional, namun tetap dapat membuat para siswa tertarik untuk membaca karena desain dibuat dengan menarik (Meikahani dan Erwin, 2015). Pada segi keterbaruan jenis media ini tidak menjadi masalah, karena penggunaan buku saku ini sudah sesuai dengan keadaan dari sasaran yang belum memungkinkan untuk dilakukan peembangan jenis media lain yang lebih modern. Situmorang dan Muhammad (2011) juga mengemukakan bahwa dalam mengembangkan teknologi baru pada suatu sasaran perlu diperhatikan aspek ketersediaan sarana dan prasarana yang diperlukan baik untuk pemanfaatan maupun perawatannya. Berdasarkan hal tersebut keberadaan buku saku "Aku Anak Sehat Bebas Cacingan" di SDN 01 Kromengan ini justru dapat mengatasi permasalahan tersebut.

Tujuan utama pengembangan buku saku "Aku Anak Sehat Bebas Cacingan" ini adalah menghasilkan sebuah media promosi kesehatan untuk meningkatkan pengetahuan dari sasaran. Maka dari itu buku saku ini berisikan materi penting terkait masalah cacingan yang ditularkan melalui tanah. Adapun materi yang ada dalam buku saku ini adalah pengertian dari cacingan, cacingan yang ditularkan melalui tanah, macamnya, bahayanya, cara penularannya, cara pencegahan dan pengobatannya. Materi yang disajikan dalam buku saku disusun berdasarkan sumber-sumber yang mutakhir berupa buku serta beberapa jurnal yang telah dikatakan sangat layak oleh ahli materi. Penyajian dilakukan dalam bahasa yang sederhana, singkat dan jelas, sistematika yang runtut dan disertai gambar di setiap penjelasannya sehingga tidak membuat jenuh ketika dibaca. Teknik penyajian yang semacam ini juga mampu untuk membantu para siswa untuk mengingat 
kembali materi yang telah disampaikan (Sulistyani, 2013). Penilaian oleh ahli materi terkait dengan materi dalam buku saku ini juga menunjukkan hasil yang sangat baik dengan kategori sangat layak pada setiap indikator penilaiannya.

Buku saku "Aku Anak Sehat Bebas Cacingan" mampu memberikan pesan dan himbauan yang diharapkan dapat merubah perilaku para siswa terhadap pencegahan cacingan ke arah yang lebih baik. Adanya himbauan tentang dampak negatif terhadap kesehatan siswa mampu menjadi rangsangan bagi sasaran untuk mengubah perilakunya (Atmoko dan Nang, 2016). Himbauan yang ada dalam buku saku adalah berupa ajakan untuk

waspada terhadap bahaya yang ditimbulkan cacingan dan ajakan untuk melakukan upaya dalam pencegahan serta menghindari hal-hal yang dapat dapat mengakibatkan tertular cacingan. Berdasarkan hasil penelitian yang telah dilakukan oleh Saputri (2009) dapat diketahui bahwa adanya sebuah pesan himbauan semacam ini dalam sebuah media mampu merubah perilaku siswa menjadi lebih sehat.

Pengembangan buku saku ini juga disesuaikan dengan tahap perkembangan kognitif siswa kelas IV sekolah dasar yang memiliki rasa ingin tahu dan minat belajar yang tinggi (Yusuf, 2016). Kalimat yang disajikan secara sederhana membuat siswa tidak merasa kesulitan untuk memahami karena pada dasarnya siswa sudah mampu memahami kalimatkalimat yang cukup rumit dalam bacaan (Sitepu, 2015). Perbandingan antara tulisan dan gambar juga tidak menjadi masalah karena siswa kelas IV sekolah dasar sudah sesuai untuk diberikan buku dengan tulisan yang lebih banyak dari gambarnya (Sitepu, 2015). Melalui buku saku diharapkan siswa dapat me-ngingat materi yang telah disampaikan dibantu dengan bacaan dan gambar yang mudah pula untuk diingat siswa. Hali ini didukung pula sengan adanya proses peningkatan kemampuan mengiingat dan berpikir siswa kelas IV SD itu sendiri (Soetciningsih dan Ranuh, 2013).

\section{KESIMPULAN}

Berdasarkan analisis pembahasan dan juga hasil kegiatan validasi oleh ahli media dan ahli materi, serta hasil uji coba maka dapat dikatakan bahwa buku saku "Aku Anak Sehat Bebas Cacingan" ini sangat layak serta dapat digunakan sebagai media dalam promosi kesehatan tentang cacingan pada siswa kelas IV SDN 01 Kromengan. Selain kelebihan tersebut pengembanagn buku saku ini memiliki kelemahan yaitu subyek uji coba yang terbatas hanya siswa kelas IV sehingga buku saku yang dihasilkan ini juga hanya dapat digunakan pada siswa di SDN 01 Kromengan khususnya kelas IV karena data penyakit cacingan yang dipaparkan adalah data dari siswa SDN 01 Kromengan. Selain itu kelemahan lainnya adalah masih belum diketahui pengaruh dari penggunaan buku saku "Aku Anak Sehat Bebas Cacingan" ini terhadap peningkatan pengetahuan siswa tentang materi cacingan yang ditularkan melalui tanah.

\section{SARAN}

Peneliti memberikan saran berupa dalam upaya pemanfaatan, diseminasi dan pengembangan lebih lanjut untuk buku saku "Aku Anak Sehat Bebas Cacingan" ini agar dapat digunakan dan disempurnakan menjadi media yang lebih baik. Berikut ini adalah saran dari peneliti terkait dengan tiga hal tersebut:

\section{Saran Pemanfaatan}

Buku saku ini dapat dimanfaatkan melalui kegiatan penyuluhan maupun media belajar mandiri yang digunakan oleh siswa. Melalui kegiatan penyuluhan buku saku dapat dibagikan pada sasaran sebelum kegiatan dimulai agar dapat digunakan dalam membantu sasaran memahami materi yang disampaikan ketika kegiatan berlangsung. Buku saku juga dapat dibagi setelah penyuluhan selesai dilaksanakan sehingga buku saku dapat digunakan sebagai media belajar siswa secara mandiri atau untuk mengingat materi dikemudian hari pada waktu dan tempat yang diinginkan. 


\section{Saran Diseminasi}

Buku saku dapat disebarkan kepada siswa di sekolah dasar secara langsung sebagai sasaran primer. Sebagai sasaran sekunder guru sekolah dasar, pembina UKS, orang tua siswa atau tenaga penyuluh kesehatan di puskesmas yang dapat menggunakannya sebagai media penyampaian informasi kepada sasaran primer. Sasaran yang ketiga atau sasaran tersier adalah kepala sekolah, puskesmas dan berbagai pihak lainnya yang dapat berperan serta dalam proses menentukan kebijakan promosi kesehatan di Sekolah Dasar.

Penyebarluasan buku saku ini juga dapat dibuat dalam bentuk media tidak tercetak. Media tidak tercetak tersebut yaitu dalam bentuk digital pada sasaran yang telah memiliki sarana untuk pemanfaatannya. Penyebarluasan dalam bentuk digital ini dapat dilakukan dalam bentuk e-book dan website sehingga dapat dengan mudah diunduh secara mandiri oleh sasaran.

\section{Saran Pengembangan Produk Lebih Lanjut}

Perlu dilakukan penelitian lebih lanjut terkait pengaruh buku saku "Aku Anak Sehat Bebas Cacingan" ini terhadap peningkatan pengetahuan tentang cacingan yang ditularkan melalui tanah pada siswa. Penelitian lanjutan terkait efektivitas buku saku cacingan ini dalam meningkatkan pengetahuan para siswa tentang penyakit cacingan yang ditularkan melalui tanah dibandingkan dengan media lain juga perlu dilakukan. Selain itu buku saku dapat digunakan sebagai dasar dalam mengembangankan media lain yang mengacu pada materi yang ada dalam buku saku ini misalnya games (permainan kartu, kuis dan lainnya) agar lebih menarik.

\section{DAFTAR RUJUKAN}

Ami, M.S., Endang, S., Raharjo. 2012. Pengembangan Buku Saku Materi Sistem Ekskresi Manusia di SMA/MA Kelas XI. Jurnal BioEdu, 1 (2): 10-13.
Andini, A., Endang, S., Sofia, E.R. 2015. Prevalensi Kecacingan Soil Transmitted Helminths (STH) pada Siswa SDN 1 Kromengan Kabupaten Malang. Jurnal Universitas Negeri Malang, 1 (2): 1-13.

Astuty. 2009. Pengaruh Penyuluhan terhadap Tingkat Pengetahuan tentang Penyakit Rabies pada Siswa Sekolah Dasar di Provinsi Sumatera Barat. Institut Per-tanian Bogor, dalam situs: (ht-tp://repository.ipb.ac.id/handle/1-23456789124457), diakses 23 Agustus 2016.

Atmoko, W.B., dan Nang A.B. 2016. Sustainability Concumption: Perubahan Perilaku Mengonsumsi Daging. Jurnal Ekonomi dan Bisnis, 19 (2): 249-261.

Balai Pengkajian Teknologi Pertanian (BPTP) Jambi. 2016. Booklet dan Buku Saku. Badan Litbang Pertanian. (Online), (http://jambi.litbang.pertanian.go.id/ind/index.php/ publikasi/mediacetak/booklet-abuku-saku), diakses 10 November 2016.

Budiono, M.A., dan Muji S. 2014. Peran UKS (Usaha Kesehatan Sekolah). Dalam Penyampaian Informasi Kesehatan Reproduksi Terhadap Siswa SMP Negeri X di Surabaya. Jurnal Promkes, 2 (1): 58-65.

Centers for Desease Control and Prevention. 2013. Soil Trans-mitted Helminth. USA: U.S. Department of Health \& Human Service. (Online), (https://www.cdc.gov/parasites/sth/), diakses 5 November 2016.

Faisal, 2013. Identifikasi Telur Cacing Ascaris Lumbricoides pada Spesimen Tinja Siswa SD Islam 03 Salafiah Singosari Kabupaten Malang. Jurnal Healthy Science, 3 (1): 1-13.

Hikmawati, Isna. 2011. Promosi Kesehatan untuk Kebidanan. Yogyakarta: Nuha Medika.

Husna, A.R., dan Reliani. 2016. Streedfood Cards sebagai Media Merubah Pengetahuan, Sikap dan Perilaku Anak Usia Sekolah dalam Meng- 
konsumsi Jajanan di SDN 1 Wonorejo Rungkut Surabaya. Jurnal Keperawatan Muhammadiyah, 1 (1): 7-14.

Kementerian Kesehatan RI. 2012. Pedoman Pengendalian Ke-cacingan. Jakarta: Direktorat Jenderal PP dan PL.

Kholid, Ahmad. 2015. Promosi Kesehatan dengan Pendekatan Teori Perilaku, Media, dan Aplikasi. Jakarta: PT Raja Grafindo Persada.

Martila, Semuel Sandy, Nopita Paembonan. 2015. Hubungan Higiene Perorangan dengan Kejadian Kecacingan pada Murid SD Negeri Abe Pantai Jayapura. Jurnal Plasma, 1 (2): 87-96.

Meikahani, R., dan Erwin S.K. 2015. Pengembangan Buku Saku Pengenalan Pertolongan dan Perawatan Cidera Olahraga untuk Siswa Sekolah Menengah Pertama.

Jurnal Pendidikan Jasmani Indonesia, 11 (1): 15-22).

Moonie, Sheniz, dkk. 2008. The Relatioship Between School Absence, Academic Performance, and Asthma Status. The Journal of School Health, 78 (3): 140-148.

Muslim, H.M. 2009. Parasitologi untuk Keperawatan. Jakarta: Penerbit Buku Kedokteran EGC. (Online), (https://books.google.co.id), diakses 10 November 2017.

Natadisastra, D., dan Ridad Agoes. 2009. Parasitologi Kedokteran: Ditinjau dari Organ Tubuh yang Diserang. Jakarta: Penerbit Buku Kedokteran EGC. (Online), (https://books.google.co.id), diakses 13 November 2016.

Notoatmodjo, S. 2011. Kesehatan Masyarakat Ilmu \& Seni. Jakarta: Rineka Cipta.

Novita, N., dan Yunetra F. 2011. Promosi Kesehatan dalam Pelayanan Kebidanan. Jakarta: Salemba Medika.

Nurani, A., dan Nugrahardi R. 2014. Perancangan Buku Interaktif Jarimatika Penjumlahan dan Pengurangan sebagai Alternatif
Pembelajaran Matematika untuk Anak Usia 5-7 Tahun. Jurnal Sains dan Seni Pomits, 3 (1): 13-17.

Nurjannah, A., dkk. 2012. Personal Hygiene Siswa Sekolah Dasar Negeri Jatinangor. Jurnal UNPAD, 1 (1): 1-14.

Okdila, Debora. 2013. Perancangan Kampanye Beserta Media Pendukung Gerakan Maridong (Mari Mendongeng) Bagi Orang Tua di Surabaya. Jurnal DKV Adiwarna, 1 (2): 1-11.

Pribadi, Harlina. 2011. Pencegahan Penyakit Menular. Bandung: PT Remaja Rosdakarya.

Rahayu, Wahyuningsih. 2015. Model Pembelajaran Komeks: Ber-muatan Nilai-nilai Pendidikan Karakter Aspek Membaca Inten-sif di SD. Jakarta: Deepublish. (Online), (https://books.google-.co.id), diakses 27 Mei 2017.

Saidah, I.T. 2015. Pengembangan Media Pembelajaran Berbentuk Permainan Edukasi Akuntansi Cari Kata (ACAK) dengan Menggunakan Software Adobe Flash CS5 untuk Pembelajaran Akuntansi Keuangan Kompetensi Dasar Aset di Kelas XI Akun-tansi SMK YPE Sawunggalih Kutoarjo Tahun 2014/2015. Jurnal Pendidikan Akuntansi Indonesia, 13 (1): 65-74.

Sandjaja, S. 2001. Pengaruh Keterlibatan Orang Tua Terhadap Minat Membaca Anak Ditinjau dari Pendekatan Stres Lingkung-an. Psikodimensia kajian ilmiah psikologi, 2(1), 17-25.

Sanyoto, Sadjiman Ebdi. 2010. Nirmana Elemen-Elemen Seni dan Desain. Yogyakarta: Jalasutra.

Saputri, Pipit Eka. 2010. Dampak Komunikasi Kampanye Global Handwashing Day dalam $\mathrm{Me}$ numbuhkan Perilaku Men-cuci Tangan pada Anak Anak (Studi pada Siswa SDN Panggung Rejo 4 Kecamatan Kepanjen Kabupaten Malang). Malang Universitas Muhammadiyah Malang. 
Sari,N.L.V., dkk. 2010. Studi Efektifitas

Buku Saku Terhadap Skor

Pengetahuan Penyakit Me-nular

Seksual pada Siswa SMA Negeri

Banyumas. Jurnal Ilmiah

Kebidanan, 1 (1): 28-36.

Setyosari, Punaji. 2012. Metode Penelitian dan Pengembangan. Jakarta: Kencana.

Sitepu, B.P. 2015. Penulisan Buku Teks Pelajaran. Bandung: PT Remaja Rosdakarya.

Situmorang, S.H., dan Muhammad S. 2011. Urgensi Pengembangan Teknologi Tepat Guna untuk UMKM di Kota Medan. Jurnal Ekonom, 14 (4): 197-208.

Soetjiningsih dan IG.N Gde Ranuh. 2013. Tumbuh Kembang Anak. Jakarta: Penerbit Buku Ke-dokteran EGC.

Sofiana, L., Sri, S., Mara, I. 2011. Fingernail Biting Increase The Risk of Soil Transmitted Helminth (STH) Infection in Elementary School Children. Health Science Journal of Indonesia, 2 (2): 81-86.

Sugiyono. 2016. Metode Penelitian Kuantitatif, Kualitatif, dan $R \& D$. Bandung: Alfabeta.

Suiraoka, I.P., dan I Dewa N.P. 2012. Media Pendidikan Kesehatan. Yogyakarta: Graha Ilmu.

Sulianta, Feri. 2015. Teknik Meracik Warna dan Koreksi Pixel. Yogyakarta: Andi.

Sulistyani, N.H.D., dkk. 2013. Perbedaan Hasil Belajar Siswa antara Menggunakan Media Pocket Book dan tanpa Pocket Book pada Materi Kinematika Gerak Melingkar Kelas X. Jurnal Pendidikan Fisika, 1 (1): 164-172.

Supiyati dan Eny R.A. 2012. Promosi Kesehatan dalam Perspektif ilmu Kebidanan. Yogyakarta: Pustaka Rihama.
Suwandi, J., dkk. 2002. Efektifitas Dosis Tunggal Berulang Mebendazol 500 mg Terhadap Trikuriasis pada Anak-Anak Sekolah Dasar Cigadung dan Cicadas, Bandung Timur. Jurnal Universitas Kristen Maranatha, 1 (2): 17-24.

Tjay, Tan Hoan, dan Kirana Rahardja. 2007. Obat-obat Penting Kasiat,

Penggunaan dan Efek-efek Sampingnya. Jakarta: PT. Elex Media Komput-indo. (Online), (https://books.google.co.id), diakses 13 November 2016.

Tjay, Tan Hoan, dan Kirana Rahardja. 2010. Obat-obat Sederhana untuk Gangguan Sehari-hari. Jakarta: PT. Elex Media Komputindo. (Online), (https://books.google.co.id), diakses 13 November 2016.

Tristyanto, N., dan Faisal. 2012. Identifikasi Cacing Penyebab Penyakit "Soil Transmitted Helminthiasis" pada Spesimen Tinja Siswa SDN 01 Kecamatan Ngajum Kabupaten Malang. Jurnal Healthy Science, 2 (1): 1- 9.

Werner, D., Carol Thuman, dan Jane Maxwell. 2010. Apa yang Anda Kerjakan bila Tidak Ada Dokter. Yogyakarta: Penerbit ANDI. (Online), (https://books.google.co.id), diakses 13 November 2016.

Widodo, Hendra. 2013. Parasitologi Kedokteran. Jogjakarta: D-Medika.

World Health Organization (WHO). 2006. Penyakit Bawaan Makan-an: Fokus Pendidikan Ke-sehatan. Jakarta: Penerbit Buku Kedokteran EGC. (Online), (https://books.google.co.id), diakses 10 November 2016.

Yusuf, Syamsu. 2016. Psikologi Perskembangan Anak dan Remaja. Bandung: PT Remaja Rosdakarya. 